\title{
Studi Eksperimen Limbah Buah Pinus Sebagai Sumber Energi Alternatif Ditinjau Dari Variasi Butiran
}

\author{
Sallolo Suluh *, Petrus Sampelawang ** \\ * Teknik Mesin Fakultas Teknik Universitas Kristen Indonesia Toraja \\ ** Teknik Mesin Fakultas Teknik Universitas Kristen Indonesia Toraja
}

\begin{abstract}
Studi Eksperimen Limbah Buah Pinus Sebagai Sumber Energi Alternatif Ditinjau Dari Variasi Butiran. Dibimbing oleh Dosen Sallolo Suluh, ST., MT. dan Ir. Petrus Sampelawang., MT. Penelitian ini bertujuan (1) Mengetahui kemampuan nilai kalor pada briket arang buah pinus ditinjau dari variasi butiran (2) Mengetahui efisiensi thermal pada briket arang buah pinus ditinjau dari variasi butiran. Metode penelitian yang digunakan yaitu metode eksperimental dengan memanfaatkan limbah buah pinus sebagai bahan bakar pada kompor untuk mendidihkan air. Hasil pengujian nilai kalor didapatkan Briket 1 yaitu $5721 \mathrm{cal} / \mathrm{gr}$, briket 2 sebesar $5340 \mathrm{cal} / \mathrm{gr}$ dan briket 3 sebesar $5686 \mathrm{cal} / \mathrm{gr}$. Hasil pengujian pembakaran menunjukkan bahwa briket 3 yang paling unggul dalam hal mendidihkan air sebanyak 3 (tiga) kali) dan efisiensi pembakaran sebesar $43,58 \%$ disusul briket 2 sebesar $33,18 \%$ dan briket 1 sebesar 32,17\% .
\end{abstract}

Keywords- briket arang buah pinus dengan variasi butiran, nilai kalor, dan efisiensi thermal. 


\section{Pendahuluan}

\section{Latar Belakang}

Dengan perkembangan zaman yang semakin maju ini, konsumsi energi bahan bakar semakin meningkat dan hanya terfokus pada penggunaan bahan bakar minyak bumi yang jumlahnya terbatas dan harganya semakin meningkat. Sehingga perlu dilakukan berbagai terobosan untuk mendapatkan sumber energi alternatif, disamping penggunaan bahan bakar minyak dan gas.

Selain minyak bumi ada tiga macam sumber hidrokarbon yaitu batu bara, gas bumi dan biomassa. Dari ketiga sumber energi tersebut, hanya biomassa yang memiliki karakter dapat diperbaharui. Biomassa secara umum dikenal sebagai bahan kering material organik atau bahan yang tersisa setelah suatu tanaman atau material organik dihilangkan kadar airnya. Biomassa sangat mudah ditemukan dari aktifitas pertanian, perkebunan, peternakan, perikanan dan limbah-limbah lainnya. Limbah biomassa menjadi salah satu pilihan sumber energi alternatif. Salah satu contoh pemanfaatan energi biomassa yang berasal dari produk limbah aktifitas kehutanan yaitu limbah buah pinus merupakan salah satu bagian dari pohon pinus yang banyak tumbuh subur daerah Sulawesi selatan khususnya Toraja Utara. Menurut data dari Dinas Kehutanan dan Perkebunan Kabupaten Toraja Utara, bahwa jumlah luas kawasan pohon pinus yang ada di Kabupaten Toraja Utara Tahun 2016 (Nanggala 560 ha, Buntao' 300 ha, Sadan 300 ha, Sanggalagi 200 ha, Rantebua 1350 ha, Rindingallo 150 ha, dan Kapala Pitu 150 ha) maka jumlah total dari 7 daerah tersebut adalah 3011 ha. Bila 1 ha lahan ditanami 1666 pohon pinus, jarak tanam 2 × 3 meter, dan produksi normal dari buah pinus dalam 1 pohon berkisar $70-80 \mathrm{~kg}$ atau rata-rata $75 \mathrm{~kg}$. Dalam 1 tahun pohon pinus berbuah 2 kali yaitu dari bulan April - Juli dan bulan November - Desember. Dari total luas lahan dikali dengan jumlah pohon / ha maka jumlah pohon pinus yang ada berkisar 5.016.326 pohon. Sehingga buah pinus yang dihasilkan dalam setahun yaitu : 5.016 .326 pohon $\mathrm{x}$ $75 \mathrm{~kg}=376.224 .450 \mathrm{~kg} \mathrm{x} 2 \mathrm{kali}$ pembuahan $=752.448 .900 \mathrm{~kg}$ atau $752.449 \mathrm{ton} /$ tahun. Maka Potensi ini cukup besar untuk dijadikan sebagai bahan bakar biomassa sebagai salah satu bahan bakar alternatif.

\section{TINJAUAN PUSTAKA}

\subsection{Pohon Pinus}

\subsubsection{Definisi Pinus}

Pinus merkusii (pinus) adalah salah satu tanaman monokotil yang mempunyai ciri khas dengan daunnya yang memipih seperti jarum dan berkelompok atau berupa sisik. Pinus memiliki strobilus jantan dan strobilus betina dalam satu pohon. Ukuran strobilus jantan lebih kecil dibandingkan dengan strobilus betina (berkayu), terletak aksilaris. Pohon berkayu (woods), strobilus bentuk konus. Tanaman Pinus merkusii secara 2 morfologis, memiliki tujuh bagian, yaitu akar, batang, tangkai, daun, bunga, buah dan biji yang masing-masing berciri khas serta mempunyai fungsi yang berbeda dalam satu tumbuhan.

\subsubsection{Klasifikasi Pinus Merkusii}

Di Indonesia, pinus mempunyai nama lain yaitu tusam. Jenis ini secara alami tersebar dari garis Bujur Timur 95 $30^{\prime}$ hingga $121^{\circ} 30^{\prime}$ dan garis Lintang Utara $22^{\circ}$ 
hingga garis Lintang Selatan $2^{\circ}$. Berdasarkan klasifikasi tumbuhan, Pinus merkusii termasuk dalam famili Pinaceae yaitu satu-satunya pinus yang penyebaran alaminya sampai Pinus merkusii termasuk dalam famili Pinaceae yaitu satu-satunya pinus yang penyebaran alaminya sampai di selatan khatulistiwa. Di Jawa dan Sulawesi Selatan merupakan hasil penanaman. Tumbuh pada ketinggian 30-1.800 mdpl pada berbagai tipe tanah dan iklim.

Curah hujan tahunan rata-rata $3.800 \mathrm{~mm}$ di Filipina dan 1.000 sampail.200 mm di Thailand dan Myanmar. Di tegakan alam Sumatra (Aceh, Tapanuli dan Kerinci), tidak satu bulan pun curah hujan kurang dari $50 \mathrm{~mm}$, artinya tidak ada bulan kering. Suhu tahunan rata-rata $19-28^{\circ} \mathrm{C}$. Adapun klasifikasinya mulai dari kingdom hingga spesies, yaitu:

1) Kingdom : Plantae (Tumbuhan)

2) Subkingdom : Tracheobionta (Tumbuhan berpembuluh)

3) Divisi : Spermatophyta (Menghasilkan biji)

4) Subdivisi : Gymnospermae

5) Kelas : Coniferinae

6) Subkelas : Dillenidae

7) Ordo : Coniferales

8) Famili : Pinaceae

9) Genus : Pinus

10) Species : Pinus merkusii Jungh dan De Vr

Pohon pinus termasuk dalam tipe pohon berumah satu dengan bunga berkelamin. Pohon pinus termasuk dalam tipe pohon berumah satu dengan bunga berkelamin tunggal. Bunga jantan dan betina dalam satu tunas. Bunga jantan berbentuk strobilus dengan panjang 2-4 cm terletak terutama di bagian bawah tajuk, sedangkan strobilus betina banyak terdapat di sepertiga bagian atas tajuk terutama di ujung dahan. Strobilus jantan dan betina dapat ditemukan sepanjang tahun. Puncak pembungaan pinus di Indonesia pada bulan Maret dan berakhir pada bulan Juni. Perkembangan menjadi buah selama 11-15 bulan.

Di Indonesia puncak pembuahan pinus pada bulan Mei sampai bulan Juli, bervariasi menurut pohon maupun antar tegakan. Pohon mulai menghasilkan benih setelah umur 10-15 tahun. Benih disebarkan oleh angin. Pinus merkusii tersebar di Asia Tenggara antara lain Burma, Thailand, Vietnam, Laos, Kamboja dan Filipina (Harahap dan Izudin, 2002). Pinus merkusii atau tusam merupakan satu-satunya jenis pinus asli Indonesia.

2.2.3. Manfaat Pinus Merkusii

Pohon pinus memiliki berbagai manfaat yang besar, baik hasil kayu maupun non kayunya. Kayu pinus digunakan untuk berbagai keperluan seperti konstruksi ringan, mebel, pulp, korek api dan sumpit Hasil non kayu berupa getah (resin) yang menghasilkan produk gondorukem dan terpentin yang bernilai jual tinggi. Minyak terpentin yang mengandung senyawa terpene biasanya digunakan sebagai pelarut untuk mengencerkan cat minyak, bahan campuran vernis, bahan pewangi lantai, pembunuh kuman, bahan baku pembuat parfum, minyak, minyak pijat aromaterapi dan bahan tambahan pembuatan permen karet sehingga menjadi kenyal dan lentur.

Produk olahan dari getah atau resin pinus yang lain adalah gondorukem. Gondorukem adalah getah dari pohon Pinus merkusii yang kemudian diolah menjadi 
gondorukem. Kegunaan gondorukem adalah untuk bahan baku industri kertas, keramik, plastik, cat, batik, sabun, tinta cetak, politur, farmasi, kosmetik dan sebagainya.

Produksi getah pinus bervariasi tergantung tingkat umur tanaman tersebut. Pohon pinus yang sudah tua, dapat menghasilkan getah antara 30-60 kg, resin murni antara 20-40 kg dan terpentin antara 7-14 kg per tahun. Selain itu tanaman pinus sangat cocok untuk rehabilitasi lahan kritis, tahan kebakaran dan dibudidayakan di tanah yang tidak subur (Hidayat dan Hansen, 2001). Bagian kulitnya dapat dijadikan sebagai bahan bakar. Abunya dapat dijadikan sebagai bahan campuran pembuatan pupuk karena mengandung kalium. Secara etnobotani kerucut pinus (strobilus) oleh pengrajin dapat dijadikan sebagai kerajinan tangan seperti aksesoris (gantungan kunci) dan sebagai hiasan rumah.

\subsection{Pembuatan Briket Arang}

Briket adalah bahan bakar padat yang dapat digunakan sebagai sumber energi alternatif yang mempunyai bentuk tertentu. Kandungan air pada pembriketan antara $10-20 \%$. Ukuran briket bervariasi dari 20-100 gram. Pemilihan proses pembriketan tentunya harus mengacu pada segmen pasar agar dicapai nilai ekonomis, teknis dan lingkungan yang optimal. Pembriketan bertujuan untuk memperoleh bahan bakar yang berkualitas yang dapat digunakan sebagai sumber energi alternatif.

Beberapa tipe/bentuk briket yang umum dikenal, antara lain : bantal (oval), sarang tawon (honey comb), silinder (cylinder, telur (egg), dan lain-lain. Adapun keuntungan dari bentuk briket adalah sebagai berikut :

1.Ukuran dapat disesuaikan dengan kebutuhan

2.Porositas dapat diatur untuk memudahkan pembakaran

3.Mudah dipakai sebagai bahan bakar.

Secara umum beberapa spesifikasi briket yang dibutuhkan oleh konsumen adalah sebagai berikut :

1.Daya tahan briket

2.Ukuran dan bentuk yang sesuai untuk penggunaannya

3.Bersih (tidak berasap), terutama untuk sektor rumah tangga

4.Bebas gas-gas berbahaya

5.Sifat pembakaran yang sesuai dengan kebutuhan (kemudahan dibakar, efisiensi energi, pembakaran yang stabil).

Adapun faktor-faktor yang perlu diperhatikan didalam pembuatan briket antara lain :

1. Bahan Baku

Briket dapat dibuat dari bermacam-macam bahan baku, seperti ampas tebu, sekam padi, serbuk gergaji, dan lain-lain. Bahan utama yang harus terdapat didalam bahan baku adalah selulosa. Semakin tinggi kandungan selulosa semakin baik kualitas briket, briket yang mengandung zat terbang yang terlalu tinggi cenderung mengeluarkan asap dan bau tidak sedap.

2. Bahan Pengikat

Untuk merekatkan partikel-partikel zat dalam bahan baku pada proses pembuatan briket, maka diperlukan zat pengikat sehingga dihasilkan briket yang kompak.

Secara umum proses pembuatan briket melalui tahap penggerusan, pencampuran, pencetakan, pengeringan dan pengepakan.

1. Penggerusan adalah menggerus bahan baku briket untuk mendapatkan ukuran butir tertentu. Alat yang digunakan adalah crusher

2. Pencampuran adalah mencampur bahan baku briket pada komposisi tertentu untuk 
mendapatkan adonan yang homogen. Alat yang digunakan adalah mixer, combining blender

3. Pencetakan adalah mencetak adonan briket untuk mendapatkan bentuk tertentu sesuai yang diinginkan. Alat yang digunakan adalah Briquetting Machine

4. Pengeringan adalah proses mengeringkan briket dengan menggunakan udara panas pada temperatur tertentu untuk menurunkan kandungan air briket

5. Pengepakan adalah pengemasan produk briket sesuai dengan spesifikasi kualitas dan kuantitas yang telah ditentukan.

Parameter yang dijadikan sebagai standar briket arang antara lain :

Nilai kalor dinyatakan sebagai heating value, merupakan suatu parameter yang penting dari suatu thermal coal. Gross calorific value diperoleh dengan membakar suatu sampel briket didalam bomb calorimeter dengan mengembalikan sistem ke ambient temperatur. Net calorific value biasanya antara 93-97\% dari gross value dan tergantung dari kandungan inherent moisture serta kandungan hidrogen dalam briket.

Dari beberapa parameter yang mempengaruhi kualitas briket, nilai kalor merupakan hal yang sangat penting untuk dibahas lebih lanjut dalam skripsi ini dengan mengabaikan parameter lain yang dapat mempengaruhi kualitas briket yaitu ; kandungan air, kandungan abu (ash), kandungan zat terbang (volatile matter) dan kandungan karbon terikat (fixed carbon).

\subsection{Teknologi Pembriketan}

Proses pembriketan adalah proses pengolahan yang mengalami perlakuan penggerusan, pencampuran bahan baku, pencetakan dan pengeringan pada kondisi tertentu, sehingga diperoleh briket yang mempunyai bentuk, ukuran fisik, dan sifat kimia tertentu. Tujuan dari pembriketan adalah untuk meningkatkan kualitas bahan sebagai bahan bakar, mempermudah penanganan dan transportasi serta mengurangi kehilangan bahan dalam bentuk debu pada proses pengangkutan.

Beberapa faktor yang mempengaruhi pembriketan antara lain:

1. Ukuran Partikel dan Distribusi

Ukuran partikel mempengaruhi kekuatan briket yang dihasilkan karena ukuran yang lebih kecil akan menghasilkan rongga yang lebih kecil pula sehingga kuat tekan briket akan semakin besar. Sedangkan distribusi ukuran akan menentukan kemungkinan penyusunan (packing) yang lebih baik.

\section{Tabel 2.1. Ukuran saringan dimensi partikel}

\begin{tabular}{|r|r|r|r|}
\hline $\begin{array}{l}\text { U.S. } \\
\text { Mesh }\end{array}$ & Microne & \multicolumn{1}{|l|}{ Inches } & \multicolumn{1}{|l|}{ Mili Meter } \\
\hline 20 & 840 & -331 & -84 \\
\hline 25 & 710 & -28 & -71 \\
\hline 30 & 590 & -232 & -59 \\
\hline 40 & 420 & -165 & -42 \\
\hline
\end{tabular}




\begin{tabular}{|r|r|r|r|}
\hline 50 & 297 & -117 & -297 \\
\hline 60 & 250 & -98 & -25 \\
\hline 70 & 210 & -83 & -21 \\
\hline 80 & 177 & -7 & -177 \\
\hline 100 & 149 & -59 & -149 \\
\hline
\end{tabular}

2. Kekerasan Bahan

Kekuatan briket yang diperoleh akan berbanding terbalik dengan kekerasan bahan penyusunnya.

\section{METODE PENELITIAN}

Metode penelitian yang digunakan adalah metode eksperimen yaitu dengan membuat briket arang buah pinus dalam bentuk silinder berlubang (sarang tawon) ditinjau dari variasi butiran, mengetahui nilai kalor $(H H V)$ briket arang buah, pengujian pembakaran briket arang buah pinus pada kompor briket, dan mengetahui efisiensi thermal $(\eta t h)$. Adapun komposisi briket ditinjau dari variasi butiran dapat dilihat pada tabel 3.1.

Tabel. 3.1. Komposisi briket ditinjau dari variasi butiran

\begin{tabular}{|l|l|l|l|l|}
\hline \multirow{2}{*}{ Variasi } & \multicolumn{3}{|l|}{ Komposisi } & \multicolumn{3}{l|}{$\begin{array}{l}\text { Arang } \\
\text { Buah } \\
\text { Butiran }\end{array}$} & $\begin{array}{l}\text { Tana } \\
\text { h Liat } \\
\text { Pinus } \\
\text { (gram) }\end{array}$ & $\begin{array}{l}\text { Tepun } \\
\text { gram } \\
\text { ) }\end{array}$ & $\begin{array}{l}\text { Air } \\
\text { Tapiok } \\
\text { a }\end{array}$ & \\
\hline Bram $)$ & (gram \\
Briket 1 & 800 & 100 & 100 & 800 \\
\hline Briket 2 & 800 & 100 & 100 & 800 \\
\hline
\end{tabular}




\begin{tabular}{|l|l|l|l|l|}
\hline Briket 3 & 800 & 100 & 100 & 800 \\
\hline
\end{tabular}

\subsection{Waktu dan Tempat Penelitian}

Penelitian ini dilaksanakan pada bulan Januari 2017. Adapun tempat penelitian yang digunakan selama proses penelitian adalah :

1. Laboratorium Jurusan Mesin Fakultas Teknik Mesin Universitas Kristen Indonesia Toraja, untuk pembuatan briket arang buah pinus, pengujian pembakaran briket pada kompor briket

2. Laboratorium Jurusan Mesin Fakultas Teknik Mesin UKIP Makassar untuk pengujian sifat fisik yaitu pengujian kuat tekan

3. Laboratorium Kimia dan Makanan Ternak Jurusan Nutrisi dan Makanan Ternak Fakultas Peternakan Universitas Hasanuddin Makassar, untuk pengujian nilai kalor $(H H V)$.

\subsection{Bahan Dan Peralatan}

Bahan dan peralatan yang digunakan adalah :

1. Bahan :
a. Buah Pinus
b. Tepung tapioka
c. Tanah liat
d. Air.

2. Peralatan :
a. Drum karbonisasi sebagai tempat pembakaran buah pinus sampai menjadi arang
b. Alat pencetak briket untuk mencetak bubuk arang buah pinus menjadi briket
c. Kompor briket berfungsi sebagai tempat pembakaran briket
d. Timbangan analog sebagai alat pengukur berat bahan briket
e. Panci aluminium berfungsi untuk mendidihkan air
f. Ketel air sebagai pemanas air
g. Pencatat waktu / Stop watch untuk megukur lama pendidihan air
h. Thermokopel untuk mengukur temperatur titik api dan titik didih air pada pengujian pembakaran

i. Gelas ukur sebagai alat ukur untuk mengukur berat air

j. Ayakan mesh 20 dan 40, mesh 30 dan 50, dan mesh 40 dan 60 sebagai alat untuk memisahkan arang yang halus dengan yang kasar setelah digiling atau ditumbuk secara manual. 


\subsection{Prosedur Penelitian}

1. Pembuatan Briket Arang Buah Pinus

2. Pengujian Nilai Kalor (HHV) Briket Arang Buah Pinus

a. Proses pembuatan briket arang buah pinus

b. Proses pencetakan briket arang buah pinus.

3. Pengujian Sifat Fisik Briket Arang Buah Pinus

4. Pengujian Pembakaran Briket Arang Buah Pinus pada kompor Briket

5. Pengujian Efisiensi Thermal ( $\eta$ th) Pembakaran Briket Arang Buah Pinus

Metode ini dilakukan dengan memanaskan sejumlah air sampai mendidih pada kompor dengan menggunakan briket tempurung sebagai bahan bakar secara. Volume air yang diukur dan massa bahan bakar briket yang digunakan dihitung, sehingga efisiensi termal dapat dihitung sebagai berikut dengan rumus berikut :

$\eta_{t h}=\frac{\left(M a \times C p_{a i r} \times\left(T_{a}-T_{b}\right)\right)+\left(M_{p} \times C p_{a l} x\left(T_{c}-T_{b}\right)\right)+(M u \times H l)}{L H V \times M b b} \ldots(2)$

dimana :

$\eta_{\text {th }} \quad$ : efisiensi termal pembakaran briket pada

kompor briket (\%).

$\mathrm{M}_{\mathrm{a}}$ : massa air mula-mula ( $\left.\mathrm{kg}\right)$,

$\mathrm{M}_{\mathrm{bb}}$ : massa briket yang telah terpakai dalam

pendidihan air(kg).

$\mathrm{M}_{\mathrm{u}} \quad$ : massa uap air $(\mathrm{kg})$.

$\mathrm{H}_{L} \quad$ : Kalor laten dari uap $(\mathrm{kJ} / \mathrm{kg})$.

$\mathrm{Cp}_{\text {air }}$ : kalor spesifik air $4.1769\left(\mathrm{~kJ} / \mathrm{kg}{ }^{0} \mathrm{C}\right)$.

$\mathrm{Cp}$ al : kalor spesifik aluminium/bahan panci $\left(\mathrm{kJ} / \mathrm{kg}{ }^{0} \mathrm{C}\right)$.

$L H V$ : nilai kalor bawah briket $(\mathrm{kJ} / \mathrm{kg})$.

$\mathrm{T}_{\mathrm{b}} \quad$ : temperatur ambien dari air

$\mathrm{T}_{\mathrm{a}}$ : temperatur uap air $\left(100{ }^{\circ} \mathrm{C}\right)$

$\mathrm{T}_{\mathrm{c}} \quad$ : temperatur panci $\left({ }^{0} \mathrm{C}\right)$

\section{HASIL DAN PEMBAHASAN}

\subsection{Hasil Penelitian}

Hasil penelitian ini meliputi : pembuatan dan spesifikasi briket arang buah pinus, pengujian nilai kalor $(H H V)$ briket arang buah pinus ditinjau dari variasi butiran, pengujian sifat fisik briket arang buah pinus, pengujian pembakaran briket arang buah pinus pada kompor briket, dan efisiensi thermal ( $\eta$ th) pembakaran briket arang buah pinus ditinjau dari variasi butiran. 
Hasil Pembuatan dan Spesifikasi Briket Arang Buah Pinus

1. Pembuatan Briket Arang Buah Pinus

Briket arang buah pinus dicetak seperti bentuk sarang tawon dengan menggunakan alat cetak briket, dan berhasil dicetak sebanyak 18 briket.

2. Spesifikasi Briket Arang Buah Pinus

Spesifikasi briket arang buah pinus yang dihasilkan terdiri dari ukuran, massa dan volume briket.

a. Ukuran Briket

Briket yang dihasilkan mempunyai dimensi rata-rata yaitu ; diameter $(\mathrm{d})=63 \mathrm{~mm}$, tinggi (l) masing-masing variasi yang dihasilkan, briket $1($ mesh 20 dan 40) $=40$ $\mathrm{mm}$, briket $2($ mesh 30 dan 50$)=38 \mathrm{~mm}$, briket $3($ mesh 40 dan 60$)=41 \mathrm{~mm}$; diameter lubang tengah briket $(\mathrm{d})=15 \mathrm{~mm}$ dan diameter masing-masing empat lubang keliling $(\mathrm{d} 1)=8 \mathrm{~mm}$.

b. Massa dan Volume Briket

1. Briket arang buah pinus sebelum dibakar pada kompor briket ditimbang massanya terlebih dahulu dengan dikelompokkan berdasarkan variasi butiran, masing-masing variasi butiran terdiri dari 3 buah briket yang ditimbang dan didapatkan massanya yaitu ; briket 1 (mesh 20 dan 40), briket 2 (mesh 30 dan 50), briket 3 (mesh 40 dan 60), masing- masing mempunyai berat rata-rata : 0,25 $\mathrm{kg}: 3$ buah briket $=83,333 \mathrm{gram} /$ briket.

2. Volume Briket 1 (mesh 20 dan 40) :

$\mathrm{V}=$ Volume keseluruhan - volume lubang tengah $-4 \mathrm{x}$ volume lubang sisi

$=\left(3,14 \times 3,15^{2} \times 4,0\right)-\left(3,14 \times 0,75^{2} \times 4,0\right)-\left(4 \times\left(3,14 \times 0,4^{2} \times 4,0\right)\right)$

$=109,524 \mathrm{~cm}^{3}$.

3. Volume Briket 2 (mesh 30 dan 50)

$\mathrm{V}=$ Volume keseluruhan - volume lubang tengah $-4 \mathrm{x}$ volume lubang sisi

$=\left(3,14 \times 3,15^{2} \times 3,8\right)-\left(3,14 \times 0,75^{2} \times 3,8\right)-\left(4 \times\left(3,14 \times 0,4^{2} \times 3,8\right)\right)$

$=104,047 \mathrm{~cm}^{3}$.

4. Volume Briket 3 (mesh 40 dan 60)

$\mathrm{V}=$ Volume keseluruhan - volume lubang tengah $-4 \mathrm{x}$ volume lubang sisi

$=\left(3,14 \times 3,15^{2} \times 4,1\right)-\left(3,14 \times 0,75^{2} \times 4,1\right)-\left(4 \times\left(3,14 \times 0,4^{2} \times 4,1\right)\right)$

$=112,261 \mathrm{~cm}^{3}$.

\subsubsection{Hasil Pengujian Nilai Kalor $(H H V)$ Briket Arang Buah Pinus}

Pengujian nilai kalor dilakukan di Laboratorium Kimia dan Makanan Ternak Jurusan Nutrisi dan Makanan Ternak Fakultas Peternakan Universitas Hasanuddin Makassar dengan hasil dapat dilihat pada Tabel 4.1.

\section{Tabel 4. 1. Hasil pengujian nilai kalor $(H H V)$}

\begin{tabular}{|c|c|c|c|c|c|}
\hline \multirow[b]{2}{*}{$\begin{array}{l}\text { Variasi } \\
\text { Butiran }\end{array}$} & \multicolumn{4}{|c|}{ Komposisi (gram) } & \multirow{2}{*}{$\begin{array}{l}\text { Nilai } \\
\text { kalor } \\
(\mathrm{kkal} / \mathrm{kg})\end{array}$} \\
\hline & $\begin{array}{l}\text { Arang } \\
\text { Buah } \\
\text { Pinus } \\
\text { (gram) }\end{array}$ & $\begin{array}{l}\text { Tanah } \\
\text { Liat } \\
\text { (gram) }\end{array}$ & $\begin{array}{l}\text { Tepung } \\
\text { Tapioka } \\
\text { (gram)) }\end{array}$ & $\begin{array}{l}\text { Air } \\
\text { (ml) }\end{array}$ & \\
\hline
\end{tabular}




\begin{tabular}{|l|l|l|l|l|l|}
\hline $\begin{array}{l}\text { Briket } \\
1\end{array}$ & 800 & 100 & 10 & 800 & 5721 \\
\hline $\begin{array}{l}\text { Briket } \\
2\end{array}$ & 800 & 10 & 10 & 800 & 5340 \\
\hline $\begin{array}{l}\text { Briket } \\
3\end{array}$ & 800 & 10 & 10 & 800 & 5686 \\
\hline
\end{tabular}

4.1.3. Hasil Pengujian Pembakaran Briket Arang Buah Pinus pada Kompor Briket Data pengujian pembakaran 3 jenis briket berdasarkan variasi butiran pada kompor briket dengan metode pendidihan air, dapat dilihat pada lampiran 4 yaitu ; briket 1 (mesh 20 dan 40) pada tabel 4.1, briket 2 (mesh 30 dan 50) pada tabel 4.2, dan briket 3 (mesh 40 dan 60) pada tabel 4.3.

Hasil pengujian pembakaran briket dapat dilihat pada tabel 4.5

Tabel. 4.5. Hasil pengujian pembakaran briket

\begin{tabular}{|l|l|l|l|l|l|}
\hline $\begin{array}{l}\text { Varias } \\
\text { Butira } \\
\mathrm{n}\end{array}$ & $\begin{array}{l}\text { Suhu } \\
\text { Api } \\
\text { Maksi } \\
\text { mum } \\
\left({ }^{\circ} \mathrm{C}\right)\end{array}$ & $\begin{array}{l}\text { Lama } \\
\text { Pembak } \\
\text { aran } \\
(\text { Menit })\end{array}$ & $\begin{array}{l}\text { Bera } \\
\text { t Air } \\
(\mathrm{Kg})\end{array}$ & $\begin{array}{l}\text { Suhu } \\
\text { Akhi } \\
\text { rir } \\
\left({ }^{\circ} \mathrm{C}\right)\end{array}$ & $\begin{array}{l}\text { Mendi } \\
\text { dihkan } \\
\text { Air } \\
(\text { Kali })\end{array}$ \\
\hline $\begin{array}{l}\text { Briket } \\
1\end{array}$ & 430 & 155 & 1,1 & 86 & 2 \\
\hline $\begin{array}{l}\text { Briket } \\
2\end{array}$ & 430 & 145 & 1,1 & 76 & 2 \\
\hline $\begin{array}{l}\text { Briket } \\
3\end{array}$ & 432 & 135 & 1,1 & 21 & 3 \\
\hline
\end{tabular}

Data hasil pembakaran briket dan pendidihan air untuk 3 jenis briket yang berbeda pada tabel 4.5, menggambarkan temperatur api briket dan temperatur air maka briket 3 (mesh 40 dan 60) yang lebih baik karena 3 kali mendidihkan air.

4.1.5. Hasil Efisiensi Thermal ( $\eta$ th) Pembakaran Briket Arang Buah Pinus Ditinjau dari Variasi Butiran 
Efisiensi thermal ( $\eta$ th) merupakan besarnya energi panas yang digunakan selama proses perubahan bentuk energy

yang bermanfaat dibagi besarnya energi panas yang dilepaskan oleh bahan bakar selama proses pembakaran. Perhitungan efisiensi thermal untuk briket 1 (mesh 20 dan 40) dapat mendidihkan air sebanyak 2 kali dan temperatur api maksimum di dapatkan sebesar $430^{\circ} \mathrm{C}$ dengan waktu pembakaran briket selama 155 menit (2,583 jam), menghabiskan 3 buah briket yang terbakar dengan berat briket sebelum terbakar adalah $0,25 \mathrm{~kg}$. Selanjutnya dapat dilihat data-datanya sebagai berikut :

1. $\eta_{t h}=$ Efisiensi thermal pembakaran briket pada kompor briket (\%)

2. $\mathrm{M}_{\mathrm{a}}=$ Massa air yang dipanaskan $(\mathrm{kg})=1,1 \mathrm{~kg}$

3. $\mathrm{Cp}_{\text {air }}=$ Kalor spesifik air $\left(\mathrm{kJ} / \mathrm{kg}{ }^{0} \mathrm{C}=4,1769 \mathrm{~kJ} / \mathrm{kg}{ }^{0} \mathrm{C}\right.$

5.

4. $\mathrm{T}_{\mathrm{a}}=$ Temperatur didih air dalam panci $\left({ }^{\circ} \mathrm{C}\right)=100{ }^{\circ} \mathrm{C}$

6.

$\mathrm{T}_{\mathrm{b}}=$ Temperatur air awal $\left({ }^{\circ} \mathrm{C}\right)=20{ }^{\circ} \mathrm{C}$

$\mathrm{M}_{\mathrm{p}}=$ Massa panci $(\mathrm{kg})=0,25 \mathrm{~kg}$

7. $\mathrm{Cp}_{\mathrm{al}}=$ Kalor spesifik aluminium/bahan panci $\left(\mathrm{kJ} / \mathrm{kg}{ }^{0} \mathrm{C}\right.$

$=0,9 \mathrm{~kJ} / \mathrm{kg}{ }^{0} \mathrm{C}$

8. $\mathrm{T}_{\mathrm{c}}=$ Temperatur api briket $\left({ }^{0} \mathrm{C}\right)=430{ }^{\circ} \mathrm{C}$

9. $\mathrm{H}_{L}=$ Kalor laten dari uap $(\mathrm{kJ} / \mathrm{kg})=2256,487 \mathrm{~kJ} / \mathrm{kg}$

10. $\mathrm{M}_{\mathrm{u}}=$ Massa uap air $(\mathrm{kg}) .=(1,1 \mathrm{~kg}-1,05 \mathrm{~kg}) \times 2=0,1 \mathrm{~kg}$

11. $L H V=$ Nilai kalor bawah briket $(\mathrm{kJ} / \mathrm{kg})$

Untuk briket 1 (mesh 20 dan 40)

$=5721 \mathrm{Cal} / \mathrm{gr} \times \mathrm{x}, 186=23948,106 \mathrm{~kJ} / \mathrm{kg}$

$=23948,106 \mathrm{~kJ} / \mathrm{kg}-3240 \mathrm{~kJ} / \mathrm{kg})=20708,106 \mathrm{~kJ} / \mathrm{kg}$

12. $\mathrm{M}_{\mathrm{bb}}=$ Massa briket yang telah terpakai $(\mathrm{kg})$

Untuk briket $1=0,25 \mathrm{~kg}-0,022 \mathrm{~kg}=0,228 \mathrm{~kg}$

Dengan menggunakan persamaan, maka diperoleh efisiensi thermal $(\eta t h)$ sebagai berikut :

Untuk briket 1 (mesh 20 dan 40)

$$
\begin{aligned}
& \eta \text { th } \frac{Q_{\text {air }}+Q_{\text {panci }}+(\mathrm{MuxHl})}{L H V x M b b} x 100 \% \ldots \ldots \ldots \ldots \ldots \ldots \ldots \ldots \ldots \ldots \ldots . . .(4.2)= \\
& \eta_{\text {th }}=\frac{(1038,47)+(254,7)+(225,649)}{0,228 \times 20708,11} \times 100 \% \\
& \eta_{\text {th }}=\frac{1518 \quad, 819}{4721,449} \times 100 \%=32,17 \%
\end{aligned}
$$

Selanjutnya hasil perhitungan efisiensi thermal $(\eta t h)$ yang sama pada briket 2 (mesh 30 dan 50) dan briket 3 (mesh 40 dan 60) dapat dilihat pada tabel 4.6.

Tabel 4.6. Data perhitungan efisiensi thermal ( $\eta$ th) briket arang buah pinus

\begin{tabular}{|l|l|l|l|l|}
\hline No. & Satuan & Briket 1 & Briket 2 & Briket 3 \\
\hline 1 & $\eta^{\text {th }}(\%)$ & 32,17 & 33,18 & 43,58 \\
\hline
\end{tabular}




\subsection{Pembahasan}

Pembahasan pada bagian ini meliputi : hasil pembuatan briket arang buah pinus, hasil pengujian nilai kalor $(H H V)$, hasil pengujian sifat fisik, hasil pengujian pembakaran briket pada kompor briket, dan hasil efisiensi thermal ( $\eta$ th) pembakaran briket arang buah pinus.

4.2.1.Hasil Pembuatan dan Spesifikasi Briket Arang Buah Pinus Untuk kualitas briket mang baik sebelum pembuatan briket, maka diperlukan pengeringan bahan baku sebelum dan sesudah pengarangan, setelah arang sudah kering, selanjutnya ditumbuk kemudian hasil penumbukan arang dipisahkan dengan menggunakan 3 jenis pasangan saringan yaitu mesh 20 dan 40, mesh 30 dan 50, dan mesh 40 dan 60 , sehingga abu dapat terbuang. Selain itu juga ditambahkan tepung tapioka dan tanah liat dengan komposisi masing-masing 10\% untuk menambah kerapatan dan kuat tekan.

4.2.2. Hasil Pengujian Nilai Kalor $(H H V)$ Briket Arang Buah Pinus Ditinjau dari Variasi Butiran

Tinggi rendahnya kadar air, kadar abu (ash), dan kadar karbon terikat, serta ukuran butir briket dapat mempengaruhi nilai kalor pada briket. Jika kadar air dan kadar abu pada briket rendah, maka akan meningkatkan nilai kalor dan sebaliknya. Semakin tinggi nilai kadar karbon terikat dalam briket arang maka semakin tinggi pula nilai kalor briket arang. Begitupun semakin besar butiran briket, maka nilai kalor pada briket akan meningkat namun jika kadar air dan kadar abu pada briket tinggi maka nilai kalor pada briket rendah.

Berdasarkan hasil pengujian Laboratorium Kimia dan Makanan Ternak Jurusan Nutrisi dan Makanan Ternak Fakultas Peternakan Universitas Hasanuddin Makassar terhadap nilai kalor (lampiran 1, halaman 52), bahwa kandungan nilai kalor yang didapatkan dalam briket 1 (mesh 20 dan 40) = 5721 cal/gr, briket 2 (mesh 30 dan 50) $=5340 \mathrm{cal} / \mathrm{gr}$, dan briket $3($ mesh 40 dan 60$)=5686 \mathrm{cal} / \mathrm{gr}$, Jadi, briket 1 (mesh 20 dan 40) mempunyai nilai kalor yang tinggi namun hanya mampu dua 
kali mendidihkan air masing-masing sebanyak 1100 gram (lampiran 3, halaman 54). Sedangkan briket 2 (mesh 30 dan 50) mempunyai nilai kalor yang sangat rendah dan hanya mampu dua kali mendidihkan air masing-masing sebanyak 1100 gram (lampiran 4, halaman 55) dan briket 3 (mesh 40 dan 60) mempunyai nilai kalor yang rendah namun mampu mendidihkan air sebanyak tiga kali masing-masing sebanyak 1100 gram (lampiran 5, halaman 56). Jadi nilai kalor ( $\eta t h)$ pada briket arang buah pinus dapat dipengaruhi oleh kadar air, kadar abu (ash), kadar karbon terikat, dan besar kecilnya butiran briket arang buah pinus.

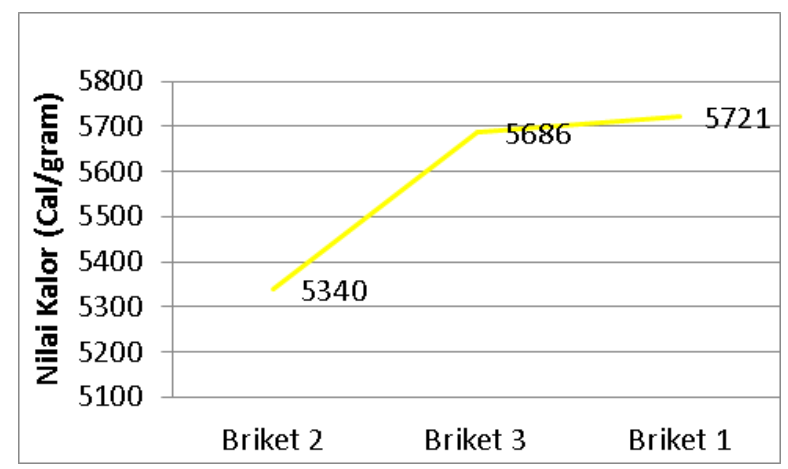

Grafik 4.1. Hubungan komposisi variasi butiran terhadap nilai kalor

4.2.3. Hasil Pengujian Sifat Fisik Briket Arang Buah Pinus

1. Kuat tekan

Pengujian kuat tekan didapatkan dari masing - masing briket arang buah pinus berdasarkan variasi butiran yaitu : briket 1 (mesh 20 dan 40$)=0,2 \mathrm{~kg} / \mathrm{cm}^{3}$, briket 2 (mesh 30 dan $50)=0,7309 \mathrm{~kg} / \mathrm{cm}^{3}$ dan briket $3($ mesh 40 dan 60$)=0,4200 \mathrm{~kg} / \mathrm{cm}^{3}($ tabel 4.3 , halaman 35).

\section{Kerapatan (densitas)}

Kerapatan briket merupakan sifat fisik briket yang berhubungan dengan kemampuan briket untuk memberi panas dan lamanya pembakaran seperti yang diperoleh pada penelitian sebelumnya. Hasil kerapatan briket yang didapatkan pada penelitian ini yaitu : briket $1($ mesh 20 dan 40$)=0,761$ $\mathrm{gr} / \mathrm{cm}^{3}$, briket $2($ mesh 30 dan 50$)=0,801 \mathrm{~kg} / \mathrm{cm}^{3}$ dan briket 3 (mesh 40 dan $60)=0,742 \mathrm{~kg} / \mathrm{cm}^{3}$, (tabel 4.4. Halaman 36).

\subsubsection{Hasil Pengujian Pembakaran Briket Arang Buah Pinus pada Kompor Briket}

Pengujian pembakaran briket, dilakukan dengan metode pendidihan air dalam panci dengan jumlah air sebanyak 1100 gram dan mencatat temperatur api dan air setiap 5 menit sampai air dalam panci mendidih. Setelah mendidih $\left(100{ }^{\circ} \mathrm{C}\right)$, kemudian air panas dikeluarkan dari panci untuk ditimbang beratnya. Setelah itu panci kembali diisi dengan air yang baru dan siap di didihkan ulang. Hal ini dilakukan secara berulangulang sampai api briket tidak bisa lagi mendidihkan air. Pengujian dilanjutkan dengan menimbang briket sisa pembakaran dan menimbang berat air yang telah mendidih. Briket yang digunakan dalam setiap kali pembakaran yaitu sebanyak tiga buah dengan berat total $=250$ gram, sedangkan berat panci aluminium yang digunakan $=250$ gram. Pembakaran briket dan pendidihan air dilakukan pada tiga jenis briket arang buah pinus berdasarkan variasi butiran (lampiran 9, halaman 61), yaitu :

Untuk briket 1 (mesh 20 dan 40), temperatur api maksimum $430{ }^{\circ} \mathrm{C}$ pada menit ke 4, dan waktu pembakarannya selama 155 menit. Sedangkan temperatur air maksimum mencapai $100{ }^{\circ} \mathrm{C}$ sebanyak 2 (dua) kali artinya briket ini dapat mendidihkan air 2 kali, dengan berat air 1100 gram sampai kemudian temperatur api menurun dan 
temperatur air konstan pada $86{ }^{\circ} \mathrm{C}$ dimenit 155, (Lampiran 3, halaman 54).

Untuk briket 2 (mesh 30 dan 50), temperatur maksimum $430{ }^{\circ} \mathrm{C}$ pada menit ke 3 dengan waktu pembakaran selama 145 menit, sedangkan temperatur air maksimun mencapai $100{ }^{\circ} \mathrm{C}$ sebanyak 2 (dua) kali, berat air 1100 gram, sampai kemudian temperatur api turun dan temperatur air konstan pada $76^{\circ} \mathrm{C}$ menit ke 145 , (lampiran 4 , halaman 55).

Untuk briket 3 (mesh 40 dan 60) temperatur maksimum $432{ }^{\circ} \mathrm{C}$ pada menit ke 4 dengan waktu pembakaran selama 135 menit, sedangkan temperatur air maksimun 100 ${ }^{\circ} \mathrm{C}$ sebanyak 3 (tiga) kali berat air 1100 gram, sampai kemudian temperatur api turun dan temperatur air konstan pada $21^{\circ} \mathrm{C}$ menit ke 135, (lampiran 5, halaman 56). Hubungan waktu pembakaran terhadap temperatur api dan temperatur air, dapat dilihat pada grafik 4.2., dan grafik 4.3.

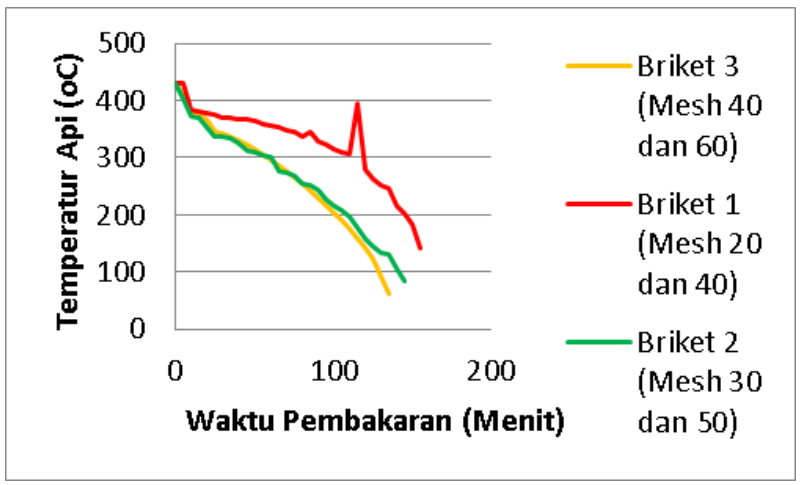

\section{Grafik 4.2. Hubungan Waktu Pembakaran Briket Terhadap Temperatur Api}

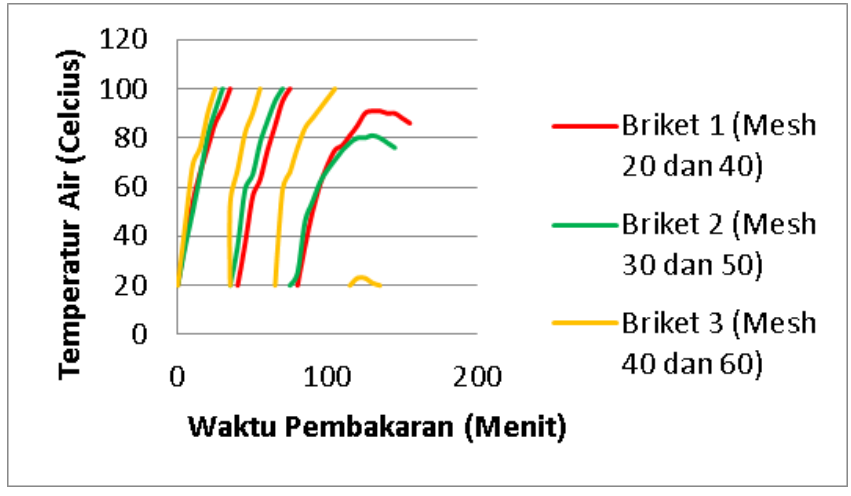

Grafik 4.3. Hubungan Waktu Pembakaran Briket Terhadap Temperatur Air

4.2.5. Hasil Pengujian Efisiensi Thermal ( $\eta t h)$ Briket Arang Buah Pinus Ditinjau dari 
Variasi Butiran

Hasil efisiensi thermal ( $\eta$ th) dari tiga jenis briket arang buah pinus berdasarkan variasi butiran dengan kemampuan mendidihkan air masing-masing jenis briket berdasarkan variasi butiran menunjukkan bahwa briket 3 (mesh 40 dan 60) memiliki waktu pembakaran briket yang lebih singkat dibandingkan briket 1 (mesh 20 dan 40) dan briket 2 (mesh 30 dan 50) dan menghasilkan efisiensi thermal tertinggi ( $\eta t h)$ sebesar 43,58\%, disusul briket 2 (mesh 30 dan 50) sebesar 33,18\%, dan yang paling rendah adalah briket 1 (mesh 20 dan 40) sebesar 32,17\%, (tabel 4.6, halaman 40).

Hal ini dapat diketahui bahwa briket 3 (mesh 40 dan 60) mempunyai butiran yang kecil dan dapat menghasilkan nyala api yang stabil, serta mampu mendidihkan air sebanyak tiga kali dengan waktu yang singkat, dan mempunyai efisiensi thermal ( $\eta t h)$ tertinggi sebesar 43,58\%. Grafik hubungan komposisi variasi butiran terhadap efisiensi thermal $(\eta t h)$ dapat dilihat pada grafik 4.4.

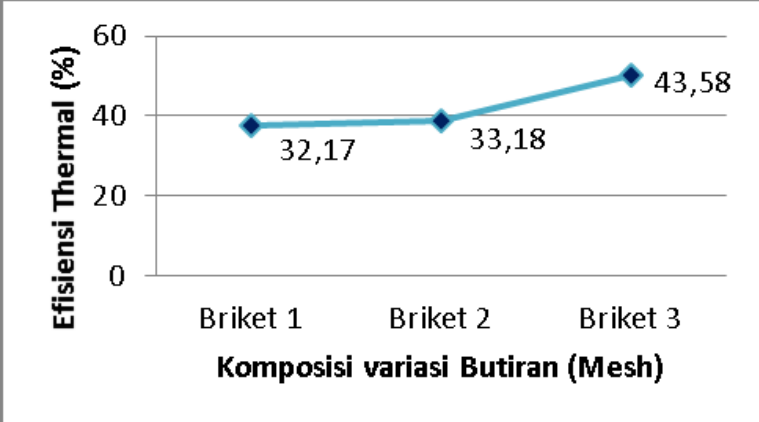

Grafik 4.4. Hubungan Komposisi Variasi Butiran (Mesh) Terhadap Efisiensi Thermal ( $\eta$ th)

BAB V

PENUTUP

\subsection{Kesimpulan}

Berdasarkan hasil penelitian, maka dapat disimpulkan sebagai berikut :

1. Hasil pengujian nilai kalor yang paling tinggi adalah B1 sebesar 5721 cal/gram, disusul B3 sebesar $5686 \mathrm{cal} /$ gram dan terakhir B2 sebesar 5340 $\mathrm{cal} /$ gram

2. Hasil pengujian pembakaran pada kompor didapatkan efisiensi thermal tertinggi adalahn B3 sebesar 43,58 \%, kemudian B2 sebesar 33,18\% dan yang paling rendah B1 sebesar 32,17\%.

\subsection{Saran}

Untuk meningkatkan nilai kalor $(H H V)$ dan efisiensi thermal $(\eta t h)$ briket arang buah pinus, maka diperlukan alat cetak yang lebih baik sehingga harapan 
bagi para peneliti selanjutnya dalam, meneliti, pengolahan dan pembuatan briket arang buah pinus dalat tercapai.

\section{DAFTAR PUSTAKA}

Arianto, 2010. Daun Kering Kakao dan Daun Kering Kayu Jati Dijadikan Sebagai Energi Alternatif. Skripsi S1 Teknik Mesin Fakultas Teknik Universitas Hasanuddin.

Daud Patabang, 2007. Studi Karakter Pembakaran Briket Arang Kulit Kemiri. Tesis Pascasarjana Teknik Mesin Unhas, Makassar.

Data Dinas Kehutanan dan Perkebunan Kabupaten Toraja Utara tahun 2014-2016 tentang Jumlah Luas Areal Penanaman Pohon Pinus yang Ada di Tujuh Desa di Kabupaten Toraja Utara, Sulawesi Selatan

Hosan, D. P. \& Arif E., 2010 Pemanfaatan Limbah Buah Pinus dan Tongkol Jagung Sebgai Sumber Bahan Bakar Alternatif. Prosiding Seminar Nasional Ritektra 2010 Universitas Atma Jaya, Jakarta.

Kurniawan Oswan. , Marsono., 2008, Superkarbon; Bahan Bakar Alternatif Pengganti Minyak Tanah Dan Gas, Penebar Swadaya,Depok.

Kardianto Pria,2009, Pengaruh Jumlah Variasi Jumlah Campuran Perekat Terhadap Karakteristik Arang Briket Batang, Semarang (UNNES)

Meli dan Muslimin (2010). Pengaruh Dimensi Arang Tempurung Kelapa Terhadap Mutu Briket. Skripsi S1 Teknik Mesin Fakultas Teknik Universitas Hasanuddin.

Syahrir M., 2011. Limbah Batang Jagung Sebagai Sumber Energi Alternatif. Laporan Penelitian Fakultas Teknik Universitas Hasanuddin.

Maidi, 2016. Uji Karakteristik Briket Arang dari Limbah Buah Pinus dengan Perekat Tepung Tapioka Sebagai Bahan Bakar Alternatif. Proposal Metode Penelitian S1 Teknik Mesin Fakultas Teknik Universitas Lambung Mangkurat Banjar Baru.

http://www.devi-alvitasari.blogspot.co.id/2013/07/identifikasi-tanaman-pinusmerkusii.html. ( Diakses pada tanggal 09 November 2016).

https://depokbebassampah.wordpress.com/acuan/briket-arang/. (Diakses pada tanggal 09 November 2016).

http://usitani.marulamsimarmata.wordpress.com/2009/02/05. Pemanfaatan Buah

Tusam (Pinus merkusii Jungh.et de Vries) dan Buah Anturmangan (Casuarina sumatrana. JUNGH) Sebagai Bahan Baku Arang Briket. Fakultas Pertanian Universitas Simalungun 